\title{
ФЕВРАЛЬСКАЯ РЕВОЛЮЦИЯ 1917 Г. И СУДЬБА ГЕНЕРАЛА РАДКО ДИМИТРИЕВА
}

\author{
С. В. Потрашков
}

Потрашков С. В. Лютнева революція 1917 р. та доля генерала Радко Димітрісва. В статті висвітлено діяльність болгарського генерала Радко Димітрієва під час Лютневої революції 1917 р. в Росії. Прийнявши революційні зміни, генерал намагався зберегти боєздатність довіреної йому армії, тому пішов на співробітництво з органами нової влади. Однак тактика сприяння «демократизації» армії призвела лише до втрати контролю над солдатською масою та довіри з боку командування. Результатом стала відставка в липні 1917 р. і завершення військової кар'єри.

Ключові слова: Перша світова війна; Лютнева революція 1917 р.; 12-та армія Північного фронту; «демократизація» армії; військові комітети.

Потрашков С. В. Февральская революция 1917 г. и судьба генерала Радко Димитриева. В статье освещается деятельность болгарского генерала Радко Димитриева во время Февральской революции 1917 г. в России. Приняв революционные перемены, генерал пытался сохранить боеспособность вверенной ему армии и пошел на сотрудничество с органами новой власти. Однако тактика содействия «демократизации» армии привела лишь к потере контроля над солдатской массой и доверия со стороны командования. Итогом стала отставка в июле 1917 г. и завершение военной карьеры.

Ключевые слова: Первая мировая война; Февральская революция 1917 г.; 12 -я армия Северного фронта; «демократизация» армии; войсковые комитеты.

Potrashkov S. V. The February 1917 Revolution and the Fate of General Radko Dimitriev. The article covers the activities of the Bulgarian General Radko Dimitriev during the February revolution of 1917 in Russia. Adopting revolutionary changes, General tried to keep fighting capacity entrusted to him army and went to cooperation with the new Government. However, the tactics of promoting the "democratization" of the army has led only to a loss of control over the soldier's mass and command confidence. The result was the resignation in July 1917 , and completion of a military career.

Keywords: World War II; the 1917 February revolution; 12 army Northern front; "democratization" of the army; military committees.

Радко Димитриев принадлежит к числу выдающихся военных деятелей Болгарии начала XX века. Значительную часть своей жизни он провел в России. Этот период его биографии наименее освещен болгарскими биографами генерала. Настоящая статья продолжает серию публикаций о службе Радко Димитриева в рядах русской армии в годы Первой мировой войны ${ }^{1}$.

Обвиненный в поражении 3-й армии Юго-Западного фронта весной 1915 г., Радко Димитриев был отставлен с поста ее командующего. В июне 1915 г. он назначается командиром 2-го Сибирского корпуса, состоявшего в резерве и в боях не участвовавшего. В октябре 1915 г. Р. Димитриев получил под командование 7-й Сибирский корпус 12-й армии Северного фронта ${ }^{2}$ В феврале 1916 г. фронт возглавил М. Н. Куропаткин, с которым у генерала были давние дружеские отношения. Ловкий царедворец, пользовавшийся доверием Николая II, Куропаткин ходатайствовал о назначении Радко Димитриева командующим 6-й армией. Просьба главнокомандующего фронтом была удовлетворена, и Р. Димитриев получил армию, правда не 6-ю, как планировал Куропаткин, а 12-ю. Михаил Лемке - журналист, служащий в царской Ставке и бывший в курсе штабных интриг, - сообщает, что царь и его начальник штаба М. В. Алексеев переменили решение главнокомандующего фронтом, так как «нашли неудобным, чтобы болгарин защищал столицу и вел операции в Финляндии». Любопытна характеристика Р. Димитриева, приводимая в записках Лемке: «Радко Димитриев любим подчиненными и войсками за свою мягкость и беззаветную личную храбрость. Однако, этих качеств у нас мало: в нашей армии нужна твердая власть и неудержимая энергия в смысле очистки авгиевых конюшен. За все время командования 3-й армией Радко Димитриев не прогнал ни одного 
начальника, не сместил даже с должности... Эта мягкость у нас не должна оцениваться положительно» ${ }^{3}$.

12-я армия прикрывала важный стратегический пункт - Ригу, и направление на Петроград вдоль побережья Балтийского моря. Весной 1916 года она насчитывала более 300 тысяч солдат и офицеров, 270 легких и 196 тяжелых орудий, 500 пулеметов ${ }^{4}$. В июле во взаимодействии с силами Балтийского флота 12-я армия предприняла наступательные действия с целью сковать силы противника и помешать их переброске на юг, где развернулось знаменитое Брусиловское наступление. Несмотря на численное превосходство и мощную огневую поддержку корабельной артиллерии, войскам не удалось прорвать оборону противника ${ }^{5}$.

«Позиционная война, прошлые неудачи, тяжелая обстановка в стране создавали гнетущее настроение в действующей армии», - вспоминал прапорщик 56-го Сибирского стрелкового полка 12-й армии - впоследствии генерал-лейтенант Советской армии и помощник заместителя Союзной контрольной комиссии в Болгарии А. И. Черепанов ${ }^{6}$ В войсках 12-й армии активную антивоенную и революционную пропаганду вели большевики, имевшие сильные позиции среди рабочих Риги и моряков Балтийского флота. Р. Димитриев видел тревожные симптомы разложения армии и считал правильным принимать для наведения порядка самые жесткие меры. Об этом свидетельствуют дневниковые записи корпусного врача 7-го Сибирского корпуса В. П. Кравкова, относящиеся к маю 1916 г.: «Между прочим, зашла речь о том, не ослабляется ли воинственный дух наших солдат тем, что ежедневно в общей прессе стали появляться целые отделы «Слухи о мире». Некоторыми было предложено запретить печатать этих отделов (так в тексте - С. П.), с ними согласился и Радко.

Разговор еще зашел о том, какие, кроме того, меры принять относительно наших бегунов и всех сеющих в войсках смуту; Радко высказался за широкое применение к ним расстрела по принципу военного времени - «лучше десять невиновных казнить, чем одного виновного не наказать» ${ }^{7}$.

Ответственность за сохранение боеспособности армии, считал он, всецело ложится на плечи офицеров. Показательна в этом отношении его беседа с младшими командирами, приводимая в воспоминаниях А. И. Черепанова. «Проведите мысленную линию взаимоотношений между офицерами и солдатами, - говорил Радко Димитриев. - Если будете держаться с солдатами выше этой линии, вы останетесь для них чужими и далекими, если опуститесь ниже этой линии, дойдете до панибратства, потеряете уважение солдат и власть над ними. Командиру роты нужно знать каждого солдата в роте, а младшим офицерам - во взводе и полуроте. Входите в их нужды, заботьтесь о них, если нужно, пишите даже за неграмотных письма родным. Спрашивайте, как живут их семьи, их дети.

Радко Димитриеву казалось, что, если офицеры найдут подход к солдатам, армию удастся спасти от развала» ${ }^{8}$.

В конце 1916 г. русское командование наметило провести в районе Риги наступательную операцию, получившую название Митавской. Цель операции, по замыслу Р. Димитриева, состояла в том, чтобы, прорвав германские позиции на широком фронте, отбросить противника и в итоге овладеть Митавой. Однако главнокомандующий войсками Северного фронта Н. В. Рузский, желая снять с себя ответственность на случай возможной неудачи, заранее объявил, что «в направлении на Митаву можно было бы попытаться произвести частную операцию, но она не обещает удачи» ${ }^{9}$. Он разрешил операцию, но лишь «в смысле боевой практики для войск», обязав Р. Димитриева обойтись силами только своей армии.

Р. Димитриев тщательно готовил порученное ему наступление. Особое значение он придавал внезапности атаки, поэтому решил провести ее в ночное время и без предварительной артиллерийской подготовки. Войска, предназначенные для наступления, прошли специальную подготовку. В тылу были оборудованы учебные городки, где проводились занятия по отработке способов ведения боевых действий ночью. Командующий армией лично объезжал воинские части и учебные подразделения, беседовал с офицерами.

Были приняты меры по дезинформации противника - имитирована переброска одного из корпусов армии на Румынский фронт. В результате всего комплекса мероприятий по подготовке наступления, проведенных Р. Димитриевым, германское командование оказалось введенным в заблуждение относительно намерений русских. 
Войска 12-й армии, предназначенные для наступления, были разделены на три оперативные группы: одингскую, бабитскую и олайскую. Главный удар наносила бабитская группа в составе 6-го Сибирского корпуса и сводной латышской дивизии.

В ночь на 23 декабря внезапно, без артиллерийской подготовки, русские войска атаковали противника. В первые же часы бабитской группе удалось добиться успеха. Немцы, застигнутые врасплох, сумели оказать сопротивление только на первой линии обороны. Особенно успешно действовали латышские стрелки. К полудню 23 декабря они прорвали всю укрепленную полосу противника и вышли ему в тыл. Путь на Митаву был свободен, никаких резервов у немцев не было.

Однако дальнейший ход операции оказался под угрозой. Накануне наступления отказались идти в атаку солдаты 17-го Сибирского полка. Никакие увещевания и угрозы не подействовали, и полк пришлось отвести в тыл. Началось следствие. Уже в ходе боев 25 декабря вышел из повиновения 55-й Сибирский полк. Его солдаты самовольно оставили отбитые у противника позиции и отошли на исходный рубеж, а затем отказались идти в новую атаку ${ }^{10}$. Известие об этом немедленно разнеслось по фронту и на время парализовало порыв атаковавших войск. Волнения грозили охватить и другие части.

Лишенные поддержки, войска бабитской группы подверглись сильным контратакам немцев, но все же сумели закрепиться в захваченном районе. Но развить наступление стало невозможным. Элемент внезапности был утерян, борьба приобрела затяжной и кровопролитный характер. 29 декабря Р. Димитриев отдал приказ о прекращении наступления. Итогом декабрьских боев стало некоторое улучшение положения русских войск под Ригой. Этот скромный успех едва ли оправдывал понесенные жертвы - 18753 солдата и 394 офицера убитыми, ранеными и пропавшими без вести ${ }^{11}$.

Не последнюю роль в срыве наступления сыграл бунт солдат 17-го и 55-го Сибирских полков. Прекрасно понимая опасность, которую представляли подобные проявления недовольства войной для сохранения дисциплины и боеспособности армии, командование подавило их самыми жестокими мерами. В телеграмме от 31 декабря 1916 г. командарм требовал от командира 6-го Сибирского корпуса широкого расследования произошедшего, выявления организаторов, предания их полевому суду и наказания по всей строгости законов военного времени ${ }^{12}$.

По приказу Р. Димитриева офицеры мятежных частей были отстранены от командования и переведены в другие полки, унтер-офицеры и ефрейторы разжалованы в рядовые. С целью выявления главных виновников было проведено расследование, по итогам которого предано военно-полевому суду и расстреляно в 17-м Сибирском полку 24 человека, в 55-м -37 человек ${ }^{13}$.

В конце января немцы попытались оттеснить части армии с завоеванных в ходе Митавской операции рубежей. Несмотря на ураганный огонь вражеской артиллерии, стрелявшей химическими снарядами, и двадцатиградусный мороз, позиции удалось отстоять. Но физическое и моральное состояние частей армии достигло тревожно низкого уровня. Военно-цензурный комитет штаба докладывал, что «в районе армии не оказалось почти ни одного полка, в котором бы процент бодрых писем превосходил $10 \%{ }^{14}$. Такой была обстановка на фронте, когда грянула Февральская революция.

Мы не располагаем документами или свидетельствами, позволяющими судить о личной оценке Р. Димитриевым событий второй русской революции. Но, зная политические взгляды генерала, можем предположить, что свержение самодержавия, замена его республиканским строем, идея созыва Учредительного собрания для решения судьбы страны нашли у него понимание и сочувствие. В этой связи уместно вспомнить о дружбе Р. Димитриева с лидером октябристов Н. И. Гучковым. Ее истоки восходили ко времени Балканской войны, когда Николай Иванович в качестве представителя Русского Красного Креста находился при штабе Радко Димитриева и оказал большую помощь в борьбе с эпидемией холеры в болгарских войсках. В бытность послом Болгарии в России Р. Димитриев навещал Н. И. Гучкова на его квартире, хотя тот состоял под надзором полиции ${ }^{15}$. Не исключено, что взгляды Р. Димитриева и Н. И. Гучкова по политическим вопросам могли быть в чем-то близкими. Вряд ли генерал скорбел об отречении императора, ибо болгарский опыт не давал оснований для слишком почтительного отношения к особе монарха. Что же до отношений с Гучковым, то не случайно первый вояж новоиспеченного военного 
министра Временного правительства на фронт в марте 1917 г. состоялся именно в армию Радко Димитриева ${ }^{16}$.

Свой первоочередной долг Р. Димитриев видел прежде всего в сохранении боеспособности вверенной ему армии и выполнении поставленных перед ним боевых задач. В этой связи у него не мог не вызвать тревоги известный Приказ № 1 Петроградского совета рабочих и солдатских депутатов от 1 марта 1917 г. В рапорте на имя Н. В. Рузского Р. Димитриев, выражая опасения, «что приказы с обращением к войскам в духе вышеупомянутого могут выкопать глубокую яму между офицерами и нижними чинами и расшатать дисциплину в основании, усердно прошу ходатайства Вашего, где следует, не допускать издания таковых. Желательно было бы разъяснять людям, пишущим такие приказы, что они толкуются широкой массой крайне неправильно и, расшатывая органическую связь между офицерами и солдатами, этим самым способствуют упадку дисциплины и духа, без которых победа немыслима ${ }^{17}$. Как видно из последней фразы, генерал оставался сторонником продолжения войны «до победного конца». Однако заставить прежде покорную массу воевать даже в «защиту свободной родины и революции» было делом весьма сложным, если не сказать невозможным. Ситуацию в армии после отречения и Приказа № 1 эмоционально и емко охарактеризовал историк-эмигрант А. Керсновский: «Солдат решил, что раз царя не стало, то не стало и царской службы и царскому делу - войне - наступил конец. ... Он с готовностью умирал за царя, но не желал умирать за пришедших к власти «господ». Офицер, призывавший солдата защищать Родину, становился ему подозрителен. Раз была объявлена «свобода», то кто имел право заставлять его, солдата, проливать свою кровь на фронте, когда в тылу рабочие провозгласили восьмичасовой трудовой день, а односельчане готовились поделить землю помещика?» ${ }^{18}$.

Человек достаточно дальновидный, Радко Димитриев понимал, что возникновение солдатских комитетов - процесс объективный и остановить его начальственной волей не удастся. Он решает, содействуя созданию комитетов, поставить их под свой контроль, чтобы использовать для поддержания дисциплины в войсках. Командующий взял на себя инициативу созыва общеармейского съезда, издав 7 марта соответствующий приказ. Съезд состоялся 9 марта в Риге. Его открыл речью сам Р. Димитриев. «Возврата к прошлому быть не может», - провозгласил он. Генерал призвал солдат и офицеров к единению, взаимному доверию и уважению ${ }^{19}$. Съезд прошел в духе «революционного оборончества». На этих позициях стоял и Исполнительный комитет Совета солдатских депутатов 12-й армии (Искосол). В подтверждение приведем эпизод из дневниковых записей британского военного атташе в России Альфреда Нокса: «Наверное, худшей в армии на тот момент была 109 дивизия, а худшим из полков этой дивизии был 436 полк, где зачинщиками мятежников стали подпоручик Хауст и прапорщик Сиверс... 20 апреля Хауст, Сиверс и девять солдат их полка прибыли на собрание представителей 12 армии и потребовали немедленного заключения мира, чтобы и немецкая, и русская стороны одновременно сложили оружие. Однако собрание, в работе которого хотя и участвовали только солдаты, не было готово пойти так далеко, и общее отношение к этой группе оказалось настолько враждебным, что лишь личное вмешательство председателя собрания солдата-еврея по фамилии Ром (Рамм - С. П.) спасло этих людей от физической расправы» ${ }^{20}$. Казалось, замысел Р. Димитриева на первых порах дал положительные результаты. Искосол, состоявший из эсеров, меньшевиков и кадетов, лояльно сотрудничал с командованием армии. Взаимодействие было настолько полным, что когда пронесся слух о предстоящем смещении Р. Димитриева с занимаемого поста, председатель Искосола обратился к Верховному главнокомандующему А. А. Брусилову с телеграммой, где признавал уход командующего 12-й армией несвоевременным ${ }^{21}$.

Однако заигрывание с комитетами имело и обратную сторону - те все чаще стали вмешиваться в вопросы относившиеся к компетенции командования. Последнее же, из-за боязни обострить остановку, шло на уступки, что не могло не повлечь за собой потерю влияния на солдатскую массу. Приведем несколько примеров. «Командир 1 Латвийской бригады полковник Аусен, - писал А. Нокс, - один из лучших офицеров армии, был вынужден уйти в отставку, так как, будучи хорошим солдатом, он не проявлял интереса к политике. И генерал Радко Димитриев, пусть и переживал за потерю такого офицера, посчитал политически правильным пойти навстречу пожеланием солдат» ${ }^{22}$. 
В другой раз Р. Димитриев обратился к командованию фронтом с просьбой содействовать смене комиссара Временного правительства в Лифляндии Красткампа, у которого возник конфликт с Рижским советом, чтобы не «озлоблять массы». В результате Красткамп был смещен и арестован по решению исполкома совета ${ }^{23}$.

Генерал отказывался арестовать уже упоминавшихся Хауста и Сиверса, «так как это приведет к кровопролитию», и они продолжали свою деятельность ${ }^{24}$. В итоге всесильные комитетчики демонстративно игнорировали воинскую субординацию. Генерал Е. А. Милоданович вспоминал о визите к Р. Димитриеву для представления по случаю вступления в командование корпусом: «Войдя в приемную, я увидел двух молодых солдат, явно еврейского происхождения (вероятно членов армейского комитета), которые полулежали на диване и не встали при моем входе. Затем 2 солдата вошли в кабинет командующего армией без доклада, а командующий корпусом должен был ждать очереди!» ${ }^{25}$.

А. И. Деникин поделил старших чинов русской армии на три группы: поощрявшие «демократизацию», не боровшиеся против «демократизации» и те, кто боролся против «демократизации». Две первые он объединил под общим наименованием «оппортунистов ${ }^{26}$. Радко Димитриев может быть причислен ко второй группе. Но его попытка «плыть по течению» в бурных водах русской революции была обречена на провал. Дисциплина в войсках падала, армия теряла боеспособность.

Наблюдавший вблизи агонию русской армии А. Нокс писал: «Было очевидно, что общее недоверие, посеянное между офицерами и солдатами агитаторами, сделало боевую эффективность русской армии нулевой. Однако командование все еще предпочитало притворяться, будто сохраняет оптимизм. Генерал Рузский заявлял, что после первого же сражения офицеры должны прийти в себя. Генерал Радко Димитриев притворялся, будто верит в то, что через два месяца его армия станет такой мощной боевой машиной, какой не была никогда прежде» ${ }^{27}$.

В начале апреля Н. В. Рузский запросил Р. Димитриева о возможности наступления на фронте его армии в мае ${ }^{28}$. Генерал, сославшись на тактические соображения, дал отрицательный ответ, добавив, что «принимая во внимание настоящее духовное состояние войск, таковые для наступательных действий в настоящее время нахожу малопригодными... Полагаю, что задаваться наступательными целями при таких условиях не желательно» ${ }^{29}$. В дальнейшем ситуация не изменилась к лучшему. В мае командующий 12-й армией сообщал в штаб фронта: «Считаю долгом донести, что развал среди солдат, несмотря на все принимавшиеся и принимаемые начальствующими лицами меры, принимает крайне угрожающие размеры.

При этих условиях удерживаться оборонительно мы еще, полагаю, сможем, но если противник соберет сильную ударную группу, то за это ручаться будет трудно, О наступлении, следовательно, в ближайшем будущем не может быть и речи» ${ }^{30}$.

В июле Р. Димитриев вынужден был констатировать, что «армия неспособна к выполнению активных боевых задач» ${ }^{31}$. Он дважды обращается к командованию фронтом с предложением отвести войска на так называемую франкендорфскую позицию с целью сократить линию фронта и отправить небоеспособные части в резерв ${ }^{32}$. Не оправдала себя попытка опереться на воинские комитеты. Они, «теряя влияние над массой, проявляют тенденцию к вмешательству во все распоряжения начальников...» ${ }^{33}$.

Отношение Р. Димитриева к большевикам было таким же, как и большинства генералов и офицеров русской армии, то есть отрицательным. В телеграммах в штаб фронта генерал именует большевиков «врагами порядка, не стесняющимися в средствах и приемах», «безответственными ораторами», играющими на «темноте и низких инстинктах массы». Результат их деятельности - это рост «злобного отношения к офицерам», «развитие тяжелых эксцессов и разложение частей» ${ }^{34}$.

Проводимая Р. Димитриевым линия на сотрудничество с войсковыми комитетами, вызвала серьезные нарекания со стороны штаба фронта и Ставки. На совещании в Ставке 16 июля новый главнокомандующий Северным фронтом генерал В. Н. Клембовский заявил, что 12-я армия «неспособна и не имеет устойчивости. Если противник против нее перейдет в наступление, она сдаст позиции»; Клембовский прямо обвинил в развале Р. Димитриева: «Он не сумел поставить себя в должное положение с комитетами и совершенно попал под их влияние. Теперь в армии открыто говорят, что не генерал Радко Димитриев 
командует армией, а председатель армейского исполнительного комитета солдат Рамм» ${ }^{35}$. Присутствовавший здесь А. Ф. Керенский отреагировал на выступление Клембовского фразой: «Радко Димитриев мне давно казался не на высоте, он слишком поддался солдатам, я хочу его убрать...» ${ }^{36}$.

Совещание признало необходимым упразднить комитеты в воинских частях, отменить «Декларацию прав солдата», ввести смертную казнь на фронте и военные суды в тылу и т.п. Р. Димитриев для проведения такой политики в армии не подходил. Это понимал Керенский, это понимал и сам генерал. Как вспоминал сослуживец Р. Димитриева по Северному фронту Ю. Н. Данилов, «создавшееся положение было особо трудным и деликатным именно для него - не коренного русского человека. Он сам чувствовал щекотливость своего положения и постарался вскоре уйти от командования армией» ${ }^{37}$.

Несколько иначе видел ситуацию А. Нокс: «Генерал Радко Димитриев оставил командование 12 армией официально по состоянию здоровья, но на самом деле от того, что он наконец убедился, что его уступки не успевают за растущими требованиями солдат» ${ }^{38}$.

7 июля, еще до совещания в Ставке, Р. Димитриев направил главнокомандующему армиями Северного фронта телеграмму следующего содержания: «Все мои усилия поддержать авторитет власти, к сожалению, разбились об упорство массы, решительно не желающей исполнять какие бы то ни было приказы, а в особенности боевого характера. Ни убеждения, ни самое широкое содействие общественных организаций не могли наладить сколько-нибудь правильные отношения между начальниками и подчиненными. Исчерпав все усилия и коренным образом подорвав свое здоровье, я чувствую себя не в силах справиться с возложенною на меня ответственною задачею, а потому прошу зачислить меня в резерв армии или уволить в отставку. Быть может, более молодой, энергичный и пользующийся авторитетом справится с задачей командования лучше, чем я» ${ }^{39}$.

Прошение об отставке было удовлетворено, и 25 июля Р. Димитриев покинул армию. Пришедший на вокзал попрощаться с командующим генерал Е. А. Милоданович был удивлен, «что провожавших его было очень мало» ${ }^{40}$.

Вскоре вместе с семьей генерал выехал для лечения на Северный Кавказ. Здесь, в Пятигорске, в ночь с 18 на 19 октября 1918 года жизнь его трагически оборвалась.

Воспитанный в традициях суворовско-драгомировской военной школы, Р. Димитриев проявлял заботу о главном труженике войны - рядовом солдате. По возможности он берег солдатские жизни. Если же обстановка требовала, то генерал, сам не раздумывая, становился под пули. Это производило впечатление на солдат, и авторитет Р. Димитриева среди них всегда был исключительно высок. Последнее обстоятельство позволило генералу сохранить контроль над армией и в первые месяцы после Февральской революции.

Р. Димитриев безоговорочно принял революцию и пошел на контакт с органами новой власти. Как типичный представитель военной касты, он слабо разбирался в социальной стороне событий и осуждал те проявления революции, которые, по его мнению, подрывали способность России продолжать войну.

Р. Димитриев не понял, что тактика потакания «демократизации» армии идет вразрез с его главной задачей - сохранить ее боеспособность. Балансируя между обязанностями командующего армией и растущими требованиями солдатской массы, генерал не сумел удержаться на линии, о которой говорил молодым офицерам накануне Митавской операции. В результате он потерял контроль над солдатами и доверие вышестоящего командования. Итогом стала отставка и бесславное завершение военной карьеры.

${ }^{1}$ Потрашков С. В. Генерал Радко Димитриев на фронтах Первой мировой войны (1914-1917 гг.) // Дриновський збірник/Дриновски сборник. Харків-Софія. 2007. Т. 1. С. 180-193; Його ж. Генерал Радко Димитриев во главе 3 армии Юго-Западного фронта // Дриновський збірник/Дриновски сборник. Харків-Софія. 2015. Т. 8. С. 287-293.

${ }_{2}^{2}$ Российский государственный военно-исторический архив (далее - РГВИА). Ф. 409. Д. 144 195. Л. 20-24.

3 Лемке М. 250 дней в царской ставке. Петроград, 1920. С. 654.

${ }^{4}$ РГВИА. Ф. 2031. Оп. 1. Д. 84. Л. 12.

${ }^{5}$ Флот в Первой мировой войне. М., 1964. Т. 1. С. 219.

${ }^{6}$ Черепанов А. И. В боях рожденная. М., 1976. С. 7. 
${ }^{7}$ Кравков В. П. Великая война без ретуши. Записки корпусного врача. М. 2014. С. 223-224.

8 Черепанов А. И. В боях рожденная. С. 19.

${ }^{9}$ Вольпе А. Фронтальный удар. М., 1931. С. 322-324.

${ }^{10}$ Хромов П. Антивоенные выступления в войсках 12-й армии Северного фронта в конце 1916 г.

// Военно-исторический журнал. 1961. № 4. С. 120.

${ }^{11}$ История латышских стрелков (1915-1920). Рига, 1972. С. 92.

${ }_{12}^{12}$ Хромов П. Антивоенные выступления в войсках 12-й армии... С. 121.

${ }^{13}$ Революционное движение в армии и на флоте в годы Первой мировой войны 1914 - февраль

1917. Сборник документов. М., 1966. С. 431, 432.

${ }^{14}$ Там же. С. 309.

${ }^{15}$ Сенин А. С. Александр Иванович Гучков. М., 1996. С. 74, 168.

${ }^{16}$ Айрапетов О. Р. Участие Российской империи в Первой мировой войне (1914-1917): 1917 год. Распад. М., 2015. С. 175.

${ }_{17}$ Революционное движение в русской армии. 27 февраля - 24 октября 1917 года. Сборник документов. М., 1968. С. 26.

${ }^{18}$ Керсновский А. История русской армии. М., 1994. Т. 4. С. 270.

${ }^{19}$ Войсковые комитеты действующей армии. Март 1917 г. - март 1918 г. М., 1982. С. 23.

${ }^{20}$ Нокс А. Вместе с русской армией. Дневник военного атташе. 1914-1917. М., 2014. С. 541.

${ }^{21}$ Стратегический очерк войны 1914-1919. Ч. VII. М., 1923.С. 174.

${ }^{22}$ Нокс А. Вместе с русской армией... С. 534.

${ }^{23}$ Капустин А. Солдаты Северного фронта в борьбе за власть Советов. М., 1954. С. 41-42.

${ }^{24}$ Нокс А. Вместе с русской армией... С. 541.

${ }^{25}$ Милоданович Е. А. На Двине в 1915-1917 гг. // Военная быль (Париж). 1973. № 120. С. 17.

26 Деникин А. И. Очерки Русской Смуты. Крушение власти и армии, февраль - сентябрь 1917. M., 1991. C. 261-262.

${ }^{27}$ Нокс А. Вместе с русской армией... С. 544, 545.

${ }^{28}$ РГВИА. Ф. 2152. Оп. 1. Д. 306. Л. 123, 124.

${ }^{29}$ Там же. Л. 126.

${ }^{30}$ Там же. Л. 130.

${ }^{31}$ Революционное движение в русской армии... С. 196.

${ }^{32}$ РГВИА. Ф. 2152. Оп. 1. Д. 306. Л. 246, 247, 263, 264.

${ }^{33}$ Революционное движение в русской армии... С. 196.

${ }^{34}$ Там же. С. 158, 195, 196.

${ }^{35}$ Стратегический очерк войны 1914-1919. Ч. VII. С. 161.

${ }^{36}$ Там же. С. 179.

37 Данилов Ю. Н. Россия в мировой войне 1914-1915 гг. Берлин, 1925. С. 335.

${ }^{38}$ Нокс А. Вместе с русской армией... С. 601.

${ }^{39}$ РГВИА. Ф. 2152. Оп. 1. Д. 306. Л. 4, 5.

${ }^{40}$ Милоданович Е. А. На Двине в 1915-1917 гг. С. 17. 